\title{
Australian Journal of Basic and Applied Sciences
}

\section{An Investigation into The Use of Engine-Sail on Catamaran Fishing Vessel}

\section{${ }^{1}$ PI Santosa, ${ }^{2}$ RB Luhulima, ${ }^{3}$ IKAP Utama}

${ }^{\text {I}}$ Department of Naval Architecture, Institut Teknologi Adhi Tama Surabaya (ITATS), Surabaya, Indonesia

${ }^{2}$ Department of Naval Architecture, Technology Faculty-Pattimura University, Ambon, Indonesia

${ }^{3}$ Department of Naval Architecture Institut Teknologi Sepuluh Nopember (ITS), Surabaya, Indonesia

Correspondence Author: Pramudya Imawan Santosa, Department of Naval Architecture, Institut Teknologi Adhi Tama Surabaya (ITATS), Jl. Arif Rahman Hakim 100, Surabaya, Indonesia

E-mail: pramudya05@itats.ac.id

Received date: 12 August 2018, Accepted date: 15 October 2018, Online date: 4 November 2018

Copyright: (C) 2018 PI Santosa,et al, This is an open-access article distributed under the terms of the Creative Commons Attribution License, which permits unrestricted use, distribution, and reproduction in any medium, provided the original author and source are credited.

\begin{abstract}
In general, the use of fossil fuel to support shipping activities is extremely large with tendency to increase from year to year. The use of fossil fuel is not only un-economical, but also not environmentally friendly. In order to reduce the use of fossil fuel hence its impact to the environment, an investigation into the combination use of sail and diesel engine was carried out on a fishing vessel. Several configurations were made in connection among service speed with wind speed, sail thrust, and propeller thrust. Finally, it was found out that the reduction use of fossil fuel of approximately $30 \%$ could be achieved as the optimum result.
\end{abstract}

Key words: fishing vessel, engine-sail combination, wind speed, sail thrust, propeller thrust.

\section{INTRODUCTION}

The goal of operating a fishing vessel is to catch fish from the ocean that fulfilling the target of mission and deliver the fish to land or to another vessel for further processing. Currently, it is apparent that the catch of fishing vessels has supplied the needs of daily food and sustains the food security for millions of people in the world, (Santosa, 2017). However, the activities have a serious impact on the increase of air pollution levels (particularly $\mathrm{CO}_{2}$ ) intothe atmosphere, because those fishing boats mainly using diesel engines and consuming fossil fuels. The impact of the activities is one of the most crucial problems in the world, thus many efforts have been done to look for solutions that the operation of fishing vessels become environmentally friendly, (Korol, 2010).

In general, the operation of a fishing boat is always associated with economic and environmental issues. Economic factor mainly includes the cost of fuel, whilst the environmental factor relates to the level of pollution produced by the ship. Economic problems and strong environmental pressures have forced ship designers and owners to create more efficient vessels to minimize the use of diesel engines as ship propulsion. Reducing magnitude of ship propulsion (and fuel consumption) can be fulfilled since the ship design stage by creating more efficient hull design and propulsion systems as well as ship operational activities or operations, in which one of it is the use of engine-sail vessels (ESV), (Utama et al, 2010).

Example of the concept is shown in Figure 1, which showing the configuration of a ship with the engine-sail driver. The concept of energy conversion in the ship's configuration is to convert fossil-fuel energy and wind energy into the required thrust force of the ship through the propeller and sail. The thrust force ( $\mathrm{T}$ ), which is generated from one or more of the ship's propulsion sources, is operated together and popularly known as the hybrid system, (Santosa, 2017).

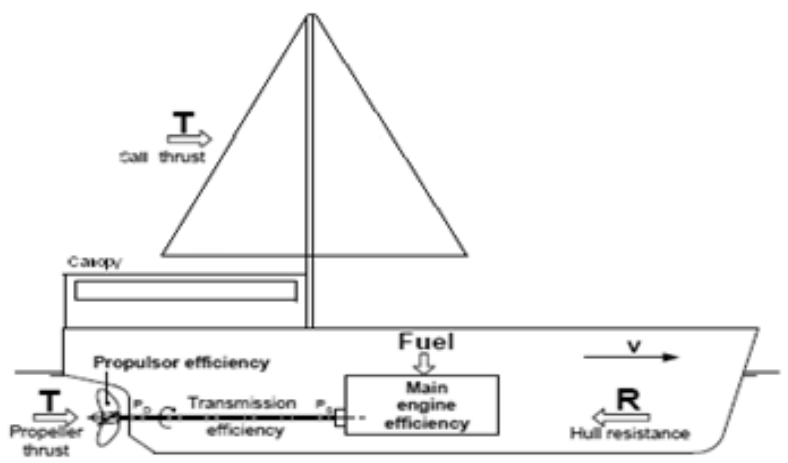

Fig 1. Configuration of engine-sail vessels (ESV), [Santosa, 2017] 


\section{LITERATURE REVIEWS}

It is well-known that a vessel move forward due to a sufficient thrust to resist ship resistance at a certain service speed, (Molland, 2011). Based on the above concept, a ship can move if its thrust $(T)$ is higher than its total resistance $\left(R_{T}\right)$. The total ship resistance $\left(R_{T}\right)$, which mainly consist of two main components i.e. viscous and wave parts, may be calculated using Equation (1) where $\rho$ is the sea water density, $\mathrm{C}_{\mathrm{T}}$ is the total resistance coefficient, WSA is the wetted surface area, and $\mathrm{V}$ is the speed of the vessel:

$R T=1 / 2 \rho C T(W S A) V^{2}$

Meanwhile, thrust $(T)$ is the energy or force required to drive the vessel and may be expressed as Equation (2):

$\operatorname{Thrust}(T)=R_{T} /(1-t)$

Where $t$ is thrust deduction factor (for single screw vessel) and for twin screw $t=k_{R}$. wt, which $k_{R}$ is 0.5 for thin rudder, and:

$$
\begin{array}{r}
w t=-0.0458+0.3745 C_{B}^{2}+0.1590 D_{w}-0.8635 F r+1.4773 F r^{2} \\
D_{w}=\frac{\pi}{F^{* w}} \sqrt{\frac{F^{N T}}{D}}
\end{array}
$$

To move itself, the thrust $(T)$ force is generated through the propeller and the sail must be greater than the existing total vessel resistance $\left(R_{T}\right)$, and mathematically expressed as:

$T$ propeller $+T$ sail $\geq R_{T}$

Propeller thrust, $T$ propeller $=K_{T} \cdot \rho \cdot n^{2} \cdot D^{4}$

Where $\mathrm{K}_{\mathrm{T}}$ is thrust coefficient, $\square$ is sea water density, $n$ is propeller rotation per minute (rpm), and D is propeller diameter.

Sail thrust, $T$ sail $=q$. As

Where dynamic wind pressure $(q)=1 / 2 \times \rho \times £ \times V_{w}{ }^{2}$ (ton $\left./ \mathrm{m}^{2}\right)$, Air mass density $(\rho)=\gamma / \mathrm{g}$, weight

per unit volume $(\gamma)=1.2265 \mathrm{t} / \mathrm{m}^{3}, \mathrm{~g}=9.81 \mathrm{~ms}^{-2}, £=$ wind pressure coefficient, wind speed $\left(V_{w}\right)$, sail area $(A s)$.

\section{Powering}

Conventional engine is the prime mover of the vessel, which works by converting the fuel energy to rotate the blades thereby producing sufficient thrust to resist ship resistance at certain service speeds. One of the most fundamental methods of power sharing in this conventional driving force is to distinguish between the effective power $\left(P_{E}\right)$ required to drive the ship and power delivered $\left(P_{D}\right)$ on the ship propulsion unit, (Molland, 2011).

The formulations to estimate $\mathrm{P}_{\mathrm{E}}, \mathrm{P}_{\mathrm{D}}$ and $\mathrm{P}_{\mathrm{S}}$ are expressed as follows:

Effective power $(P E)=R_{T} x V_{s}$

Delivered power $(P D)=P E / \eta d$

Quasi propulsive coefficient $(\eta D)=\eta P . \eta H . \eta R$

Service power $(P S)=P D / \eta T$

where: $\eta \mathrm{T}$ is 0.98 with gearbox, 0.95 without gearbox

Installed power $(P I)=P s+$ Margin

Margins (roughness, fouling, weather) 15 - 20\% depend ship route.

Meanwhile, sail is one of the propulsion devices on the ship without a propeller on the ship that can work due to the wind force on the surface of the sail, resulting in a drifting force on the ship at a certain speed. As with other propulsion devices such as propellers, the sail is attempted to produce an optimal thrust force, in order to produce maximum velocity of the ship. The forces on the sailing ship, as the ship moves due to the thrust of the propeller or sail there will be a lift that will lift the hull from the water. In addition, obstacles caused by the aerodynamic resistance of the sail are the forces acting on the sailboat, (Marchaj, 2003). Determination of sail area almost as a comparison of sail area (As) with wetted surface area (WSA) is between 2.0 and 2.5 . Comparison of sail area (As) with wetted surface area (WSA) known as sail ratio (SR) (Larson L., 2007) There is another way according to (Kinney, 1977), where the determination of $S R$ depends on the $L W L$ of the ship by using the graph shown in Figure 2.

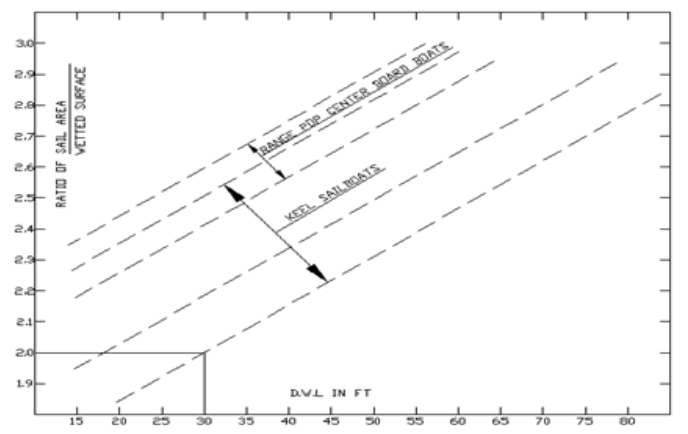

Fig 2. Graph of $S R-L W L$ Relationship, [Kinney, 1977] 
Figure 2 shows the relation between SR and LWL, which can be used to determine sail area with 15-80 feet or 5 - 25 m of LWL limitation.

\section{Voyage Profile}

In general, the normal voyage profile of fishing vessels according to [9], are: a) The ship departs and operates in the port (Departure from port), b) The ship goes to the location of the fishing ground (Outward bound), c) The ship arrives at the location fishing ground and fishing (On fishing ground), d) When the ship leaves the location of the fishing ground to the port (Homeward bound), e) when the ship arrives at the port and docked at the port (Arrival at Port).

In its operation a fishing vessel must be completely safe (very seaworthy indeed), in bad weather even the ship must operate. All work on the fishing boat must be done quickly, starting from the process of catching until the processing of the catch is a function of time. The slow catching process causes the fish to run all (migration), while the sluggish processing of the catch causes the fish to be damaged, (Hind, 1982).

\section{METHOD AND RESULT}

Experimental model test on a symmetrical catamaran has been carried out and reported in (Utama, 2010). The experimental model test was carried out at ITS towing tank as shown in Figure 3 and the principle particular of the model and full ship was given in Table 1.

Table 1: Principle Particular

\begin{tabular}{|c|c|c|}
\hline Parameter & Catamaran & Demihull \\
\hline LWL (m) & 14.5 & 14.5 \\
\hline $\mathrm{B}(\mathrm{m})$ & 7.118 & 1.318 \\
\hline $\mathrm{H}(\mathrm{m})$ & 1.44 & 1.44 \\
\hline $\mathrm{d}(\mathrm{m})$ & 0.694 & 0.694 \\
\hline $\mathrm{CB}$ & 0.434 & 0.434 \\
\hline Displacement (ton) & 11.8 & 5.9 \\
\hline
\end{tabular}

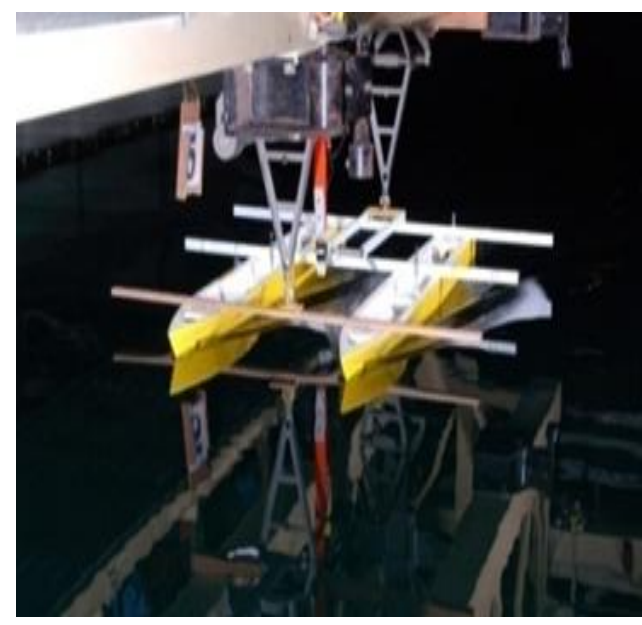

Fig 3. Experimental model test

Table 2 showed the results of resistance test which indicated that the wider the separation between the hulls $(\mathrm{S} / \mathrm{L})$, the lower the total resistance.

Table 2. Result of Resistance Test [3]

\begin{tabular}{|c|c|c|c|c|c|}
\hline Run & \multirow{2}{*}{\begin{tabular}{c}
\multirow{2}{*}{ Vo. } \\
V (knots)
\end{tabular}} & \multirow{2}{*}{ Fr } & \multicolumn{3}{|c|}{ Catamaran Resistances $(\mathrm{kN})$} \\
\cline { 4 - 6 } & & & $\mathrm{S} / \mathrm{L}=0.2$ & $\mathrm{~S} / \mathrm{L}=0.3$ & $\mathrm{~S} / \mathrm{L}=0.4$ \\
\hline 1 & 5.788 & 0.250 & 1.821 & 1.659 & 1.659 \\
\hline 2 & 6.218 & 0.268 & 2.141 & 1.851 & 2.061 \\
\hline 3 & 6.677 & 0.288 & 2.443 & 2.239 & 2.348 \\
\hline 4 & 7.051 & 0.304 & 2.852 & 2.678 & 2.947 \\
\hline 5 & 7.560 & 0.326 & 3.460 & 3.568 & 3.547 \\
\hline 6 & 8.032 & 0.347 & 4.467 & 3.954 & 3.766 \\
\hline 7 & 8.384 & 0.362 & 4.844 & 4.345 & 4.341 \\
\hline 8 & 8.818 & 0.380 & 5.149 & 4.790 & 4.662 \\
\hline 9 & 9.233 & 0.398 & 5.807 & 5.592 & 5.515 \\
\hline 10 & 9.813 & 0.423 & 7.101 & 6.448 & 6.138 \\
\hline
\end{tabular}

Data from Table 2 is further used as a basis for designing the concept of catamaran fishing boat with a combination of engine-sail.

Based on the results in Table 2, it can be calculated and thus provided the effective power (PE) of $32.4 \mathrm{~kW}$. With the quasi-propulsive coefficient $(\eta D)$ of 0.664 , then the delivered power $(P D)$ will be of $50.21 \mathrm{~kW}$ and with the transmission losses $(\eta T)$ without gearbox of 0.98 will give service power $(P s)$ of $51.2 \mathrm{~kW}$. Finally, if the total efficiency $(P E / P I)$ is $54 \%$, it yields the installed power $(P I)$ of $60 \mathrm{~kW}$. The engine specifications used $2 \times 43 \mathrm{HP}$ or $2 \times 30 \mathrm{~kW}$ as shown in Figure 4. 


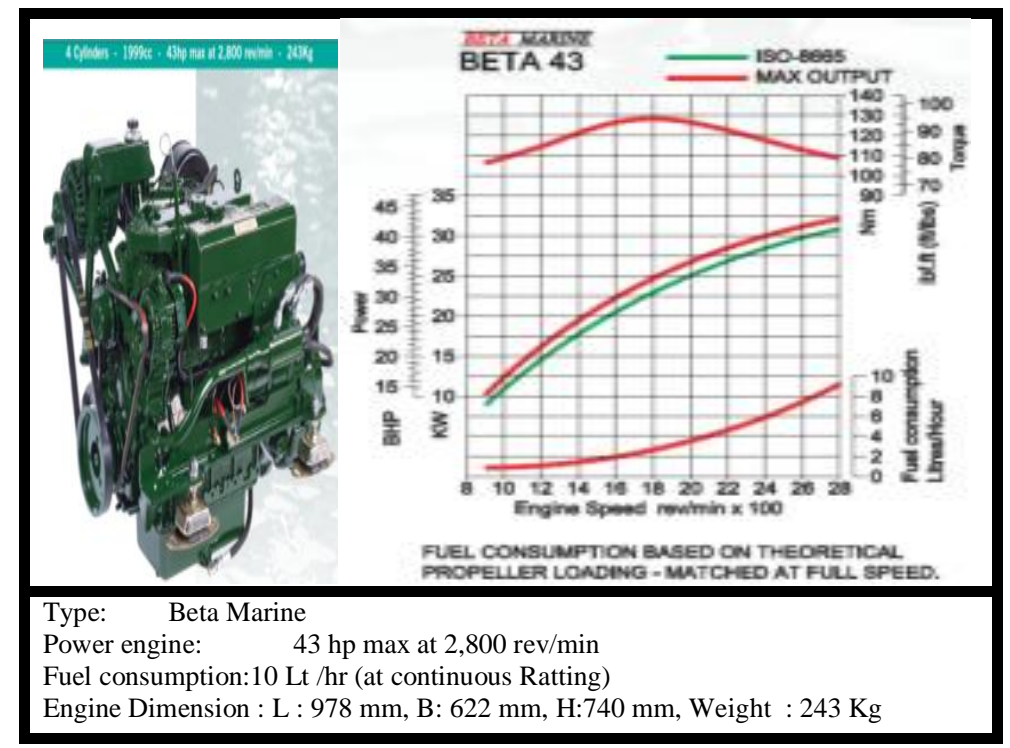

Fig 4. Specification of BETA43 engine series (http://betamarineengines.com/)

Furthermore, by using Figure 2 it can be found that the boat with $14.5 \mathrm{~m} \mathrm{LWL}$ will have approximately $125 \mathrm{~m}^{2}$ of sail area. Meanwhile, the calculation of thrust $(T)$ is obtained from Table 2, which is $6.685 \mathrm{kN}$ and with thrust deduction factor $(\mathrm{t})$ of 0.038 . The Propeller thrust $(T p)$ is obtained at the service speed $(V s)$ of 9.8 knots while the thrust force $(T s)$, calculated using Equation (7) is reached at wind speed (Vw) of 19.2 knots. A hybrid curve chart was further derived from the above calculation and shown in Figure 6. The curve can be used to estimate the efficiency of ESV.

\section{DISCUSSION}

It can be found from the tank test work as reported in [3] that at the service speed (Vs) of 9.81 knots, the total resistance $\left(\mathrm{R}_{\mathrm{T}}\right)$ is $6.14 \mathrm{kN}$, thus the installed engine power (PI) required is $60 \mathrm{~kW}$ or $2 \times 30 \mathrm{~kW}$ to adjust the shape of catamaran. The specifications of engine was shown in Figure 4 together with its characteristics shown in Figure 5.

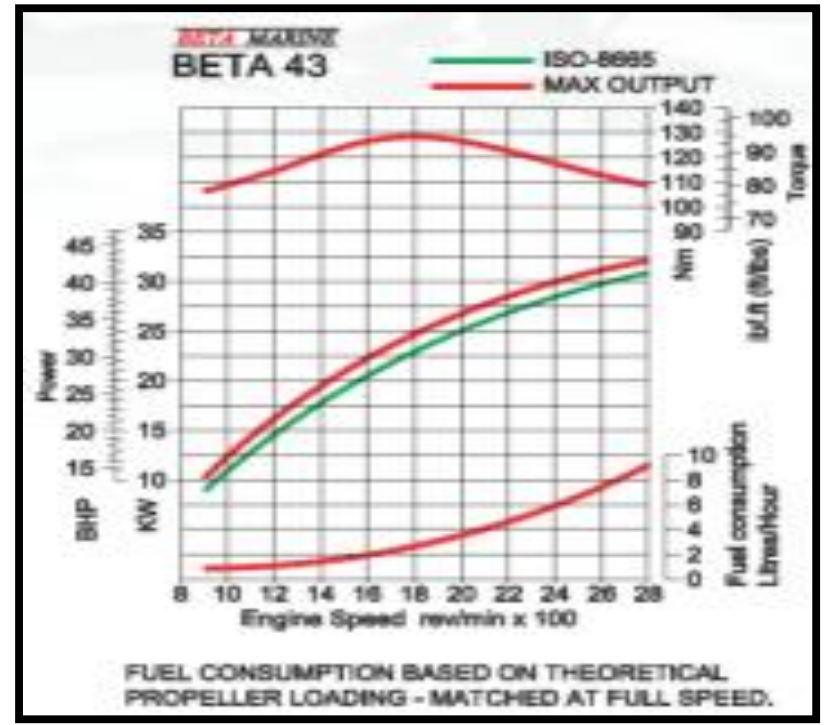

Fig 5. Engine characteristicsof BETA43 Series(Source: http://betamarineengines.com/)

Figure 5 shows the characteristics of the BETA43 engine connecting the engine running (rpm), engine power (P), fuel consumption (FC) and engine torque (Q). The maximum engine speed is $2800 \mathrm{rpm}$ with fuel consumption of about 10 liters/hour and $110 \mathrm{Nm}$ engine torque. Furthermore, Figure 5 can be used as a reference to calculate the efficiency of fishing vessel. By using Equation(4), it can be determined that the magnitude of thrust deduction factor ( $t$ ) is 0.038 , hence the thrust of ship (T) is $6.685 \mathrm{kN}$, whilst the total ship resistance is $6.138 \mathrm{kN}$. It means that as the thrust is greater than total ship resistance thus the boat will move, sea also Equation (1). As the fishing vessel is designed to use engine and sail drive (ESV), the generation of thrust to move the ship comes from propeller and sail. When the ship moves, the propeller and sail can work individually/separately or together as a hybrid system both with service speed (Vs) of 9.813 knots. 


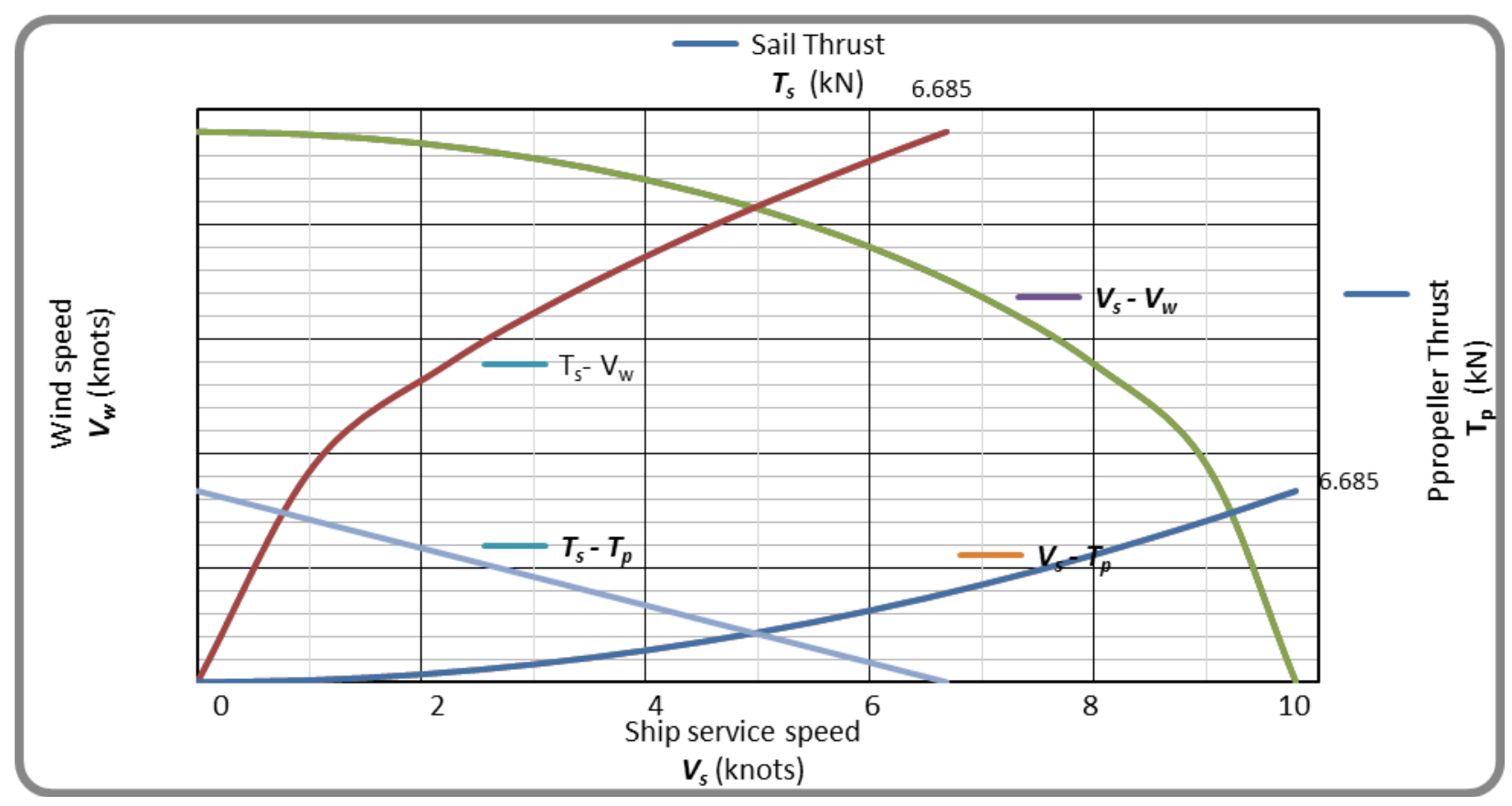

Figure 6. Hybrid Curve Chart[1]

The relationship between propeller thrust $\left(T_{P}\right)$, see Equation (3) and sail thrust $\left(T_{S}\right)$, see Equation (7) is shown in Figure 6, namely $T_{P}-T_{S}$ curve. Meanwhile, the relationship between wind speed $\left(V_{W}\right)$ with the sail thrust $\left(T_{S}\right)$ is shown in Figure 6, namely the $V_{W}-T_{S}$ curve. Likewise, the relationship between ship service speed $\left(V_{S}\right)$ and propeller thrust $\left(T_{P}\right)$ is also shown in Figure 6, namely the $V_{S}-T_{P}$ curve. The relationship between wind speed $\left(V_{W}\right)$ and ship service speed $\left(V_{S}\right)$ is called the $V_{W}-V_{S}$ curve.

Table 3. Details of Hybrid Curve Chart

\begin{tabular}{|c|c|c|}
\hline No & Number of Axis & \multicolumn{1}{|c|}{ Relationship of } \\
\hline 1 & Axis $\underline{\mathbf{1}}$ is $\boldsymbol{T}_{s}$ Sail Thrust (kN), & $\boldsymbol{T}_{s}-\boldsymbol{T}_{p}$ Curve use ordinate $\underline{\mathbf{1}}$ and abscise $\underline{\mathbf{2}}$ \\
\hline 2 & Axis $\underline{\mathbf{2}}$ is $\boldsymbol{T}_{p}$ Propeller Thrust (kN) & $\boldsymbol{V}_{s}-\boldsymbol{V}_{w}$ Curve use ordinate $\underline{\mathbf{3}}$ and abscise $\underline{\underline{4}}$ \\
\hline 3 & Axis $\underline{\mathbf{3}}$ is $\boldsymbol{V}_{s}$ Ship speed (knots) & $\boldsymbol{V}_{s}-\boldsymbol{T}_{p}$ Curve use ordinate $\underline{\mathbf{3}}$ and abscise $\underline{\mathbf{2}}$ \\
\hline 4 & Axis $\underline{\mathbf{4}}$ is $\boldsymbol{V}_{w}$ Wind speed (knots) & $\boldsymbol{T}_{s}-\boldsymbol{V}_{w}$ Curve use ordinate $\underline{\mathbf{4}}$ and abscise $\underline{\underline{4}}$ \\
\hline
\end{tabular}

Table 3 shows number of axis and relationship of Hybrid Curve Chart as shows in FIG.6. The economic value of the use of wind energy is equated with the economic value of fossil energy use, then to calculate the ESV efficiency and how the hybrid system at SV will be explained in detail in the following case study. In order to test the validity of the present approach as summarized in Figure 6, 2 case studies are given, namely Case Study 1 and Case Study 2.

\section{Case study 1}

It is assumed that a fishing vessel uses hybrid driving force (engine, sail) and operated at a service speed $\left(\mathrm{V}_{\mathrm{S}}\right)$ of 9.8 knots, whilst the sea breeze blows $\left(\mathrm{V}_{\mathrm{W}}\right)$ with a speed of 12 knots. Furthermore, estimate thrust caused by $T_{S}$ screen/sail, thrust generated by $T_{P}$ propeller, the propeller contribution to $V_{S}$ hence the vessel can be operated at the service speed of 9.8 knots, and the fuel consumption $\left(\mathrm{F}_{\mathrm{C}}\right)$.

The answers is described as follows:

For completion of CS1 using FIG. 7 Hybrid Curve Chart, FIG. 8 Rpm-Vs Chart, and FIG. 9 Rpm-FC Chart. Choice value of 12 kts Vw Wind speed in the axis and then generate horizontal line $\underline{\mathbf{4}}$ through pass the $T s-V w$ curve and the $V s-V w$ curve, next from the intersection it drags the vertical line $\underline{\mathbf{b}}$ and $\underline{\mathbf{c}}$. From the intersection of the line $\underline{\mathbf{a}}$ with the curve $T s-T p$ drag a horizontal line $\underline{\mathbf{d}}$, (see green line in FIG.7). The results of Hybrid Curve Chart readings obtained: ${ }^{1}$ ) Line $\mathbf{b}$ with the axis $\mathbf{1}$ is obtained $2.4 \mathrm{kN} \mathrm{Ts},{ }^{2)}$ Line $\mathbf{c}$ with the axis $\mathbf{3}$ is obtained $7.6 \mathrm{knots} V s,{ }^{3)}$ Line $\mathbf{d}$ with the axis $\mathbf{2}$ is obtained $4.3 \mathrm{kN} T p$. Furthermore, use FIG. 8 to find: When the rotation of engine abt. $1300 \mathrm{Rpm}$ obtained $7.67 / 2=3.835 \mathrm{knots} V$ s. (See red line), and then use FIG.9 to find: When the rotation of engine about $1300 \mathrm{Rpm}$ obtained magnitudes of fuel consumption (FC)is abt. 1.8 liter /hour /engine or 3.6 liter /hour (see red line). Finally, results of the completion of CS1is

When 12 knots wind speed $(V w)$ blows on the sail generates $2.4 \mathrm{kN}$ sail thrust (Ts) and automatically propeller thrust $(T p)$ is abt. $4.285 \mathrm{kN}$ with the contribution of servicing ship speed $V s$ of 7.67 knots and 3.6 liter/hour fuel consumption $(F C)$. 
Citation: PI Santosa, et al., An Investigation Into The Use of Engine-Sail on Catamaran Fishing Vessel. Australian Journal of Basic and Applied Sciences, 12(10): 47-54. DOI: 10.22587/ajbas.2018.12.10.8

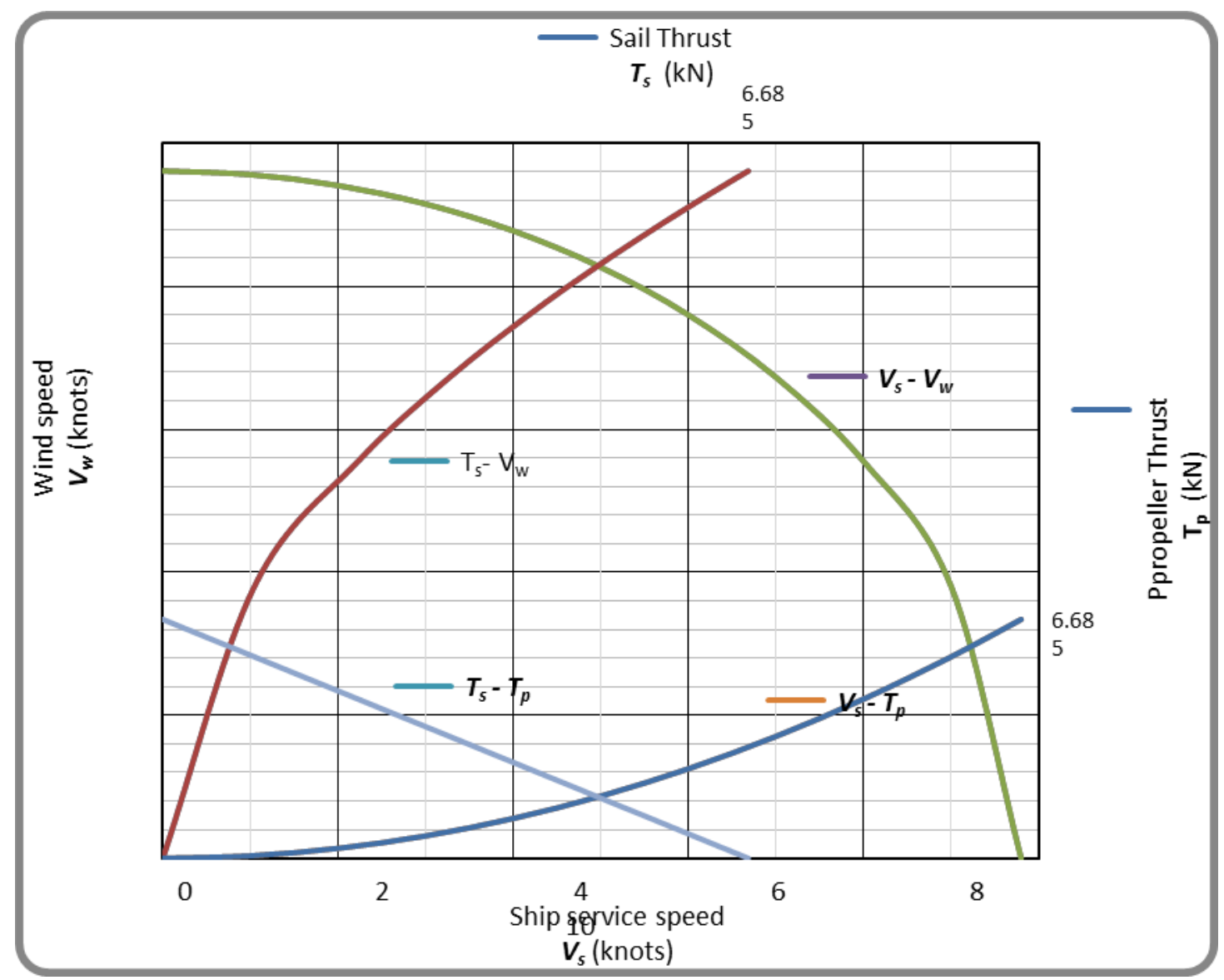

Figure 7. Application of CS1 use Hybrid Curve Chart

Figure 8.Rpm-Vs Chart

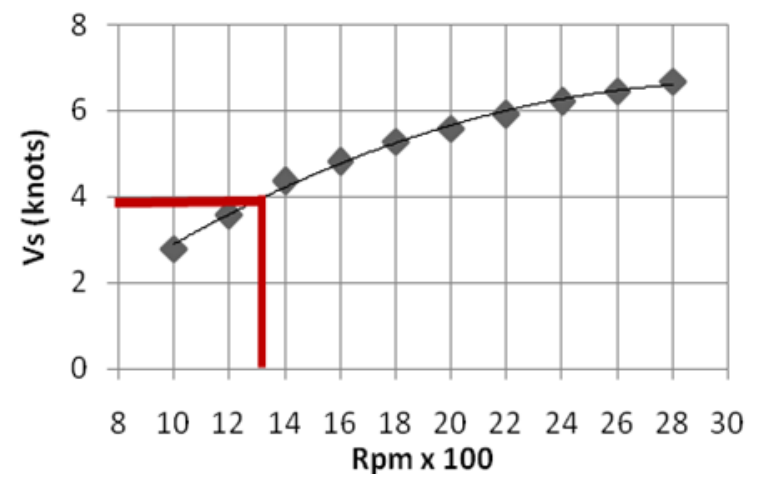

Figure 9. Rpm-FC Chart

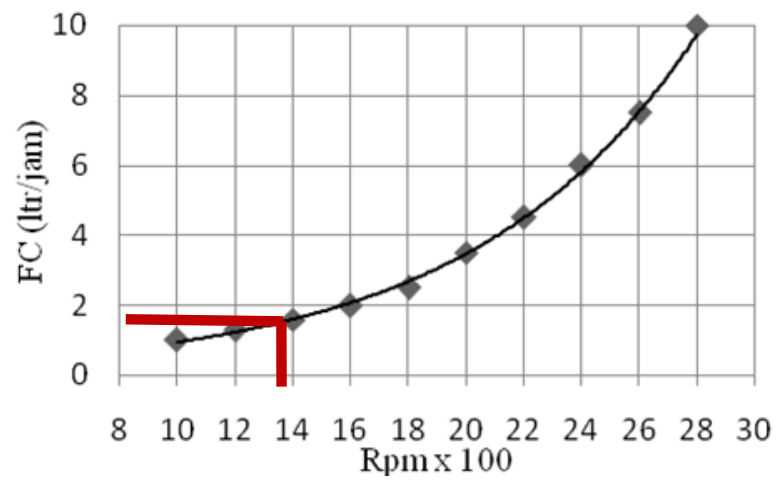

Case Study 2 
Citation: PI Santosa, et al., An Investigation Into The Use of Engine-Sail on Catamaran Fishing Vessel. Australian Journal of Basic and Applied Sciences, 12(10): 47-54. DOI: 10.22587/ajbas.2018.12.10.8

When ESV is operated the sea breeze blows $\left(V_{W}\right)$ with the varying speeds of 0.0, 4.0, 8.0, 16.0, and 19.2 knots. By using Hybrid Curve, Rpm-V $V_{S}$, and Rpm$F_{C}$, estimate: thrust of sail $\left(T_{S}\right)$, thrust of propeller $\left(T_{P}\right)$, contribution of propeller to $T_{S}$ thus the vessel can be operated at the service speed $(V s)$ of about 9.813 knots, and the fuel consumption $\left(F_{C}\right)$.

In the same way as in CS1, the following results obtained are: (see FIG. 10 and 11)

Table 4. The Hybrid System work at the service speed (Vs) 9.813 knots

\begin{tabular}{|c|c|c|c|c|c|}
\hline \multicolumn{2}{|c|}{ Sail } & \multicolumn{2}{c|}{ Propeller } & \multirow{2}{*}{$\boldsymbol{F C / E n g i n e ~ ( L i t e r / h o u r ) ~}$} & \multirow{2}{*}{ Prime mover } \\
\cline { 1 - 4 } $\boldsymbol{V w}$ (Knots) & $\boldsymbol{T s}(\boldsymbol{k N})$ & $\boldsymbol{T p}(\boldsymbol{k N})$ & Engine $\boldsymbol{R p m}$ & 4.5 & Engine \\
\hline 0.0 & 0 & 6.685 & 1700 & 3.8 & Engine-sail \\
\hline 4.0 & 0.5 & 6.185 & 1550 & 3.7 & Engine-sail \\
\hline 8.0 & 1.2 & 5.485 & 1480 & 2 & Engine-sail \\
\hline 16.0 & 5.4 & 1.285 & 1000 & 0 & Sail \\
\hline 19.2 & 6.685 & 0 & 0 & & \multirow{2}{*}{} \\
\hline
\end{tabular}

Table 4 shows the Hybrid System (ESV) work, the propeller and sail can work individually/separately or together as a hybrid system when the ship moves.

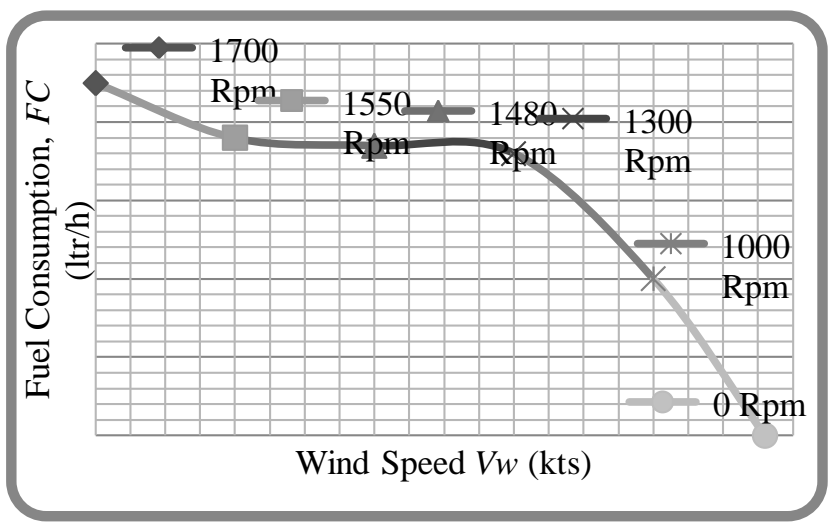

Figure 10. Result of CS2 use Vw-FC Chart

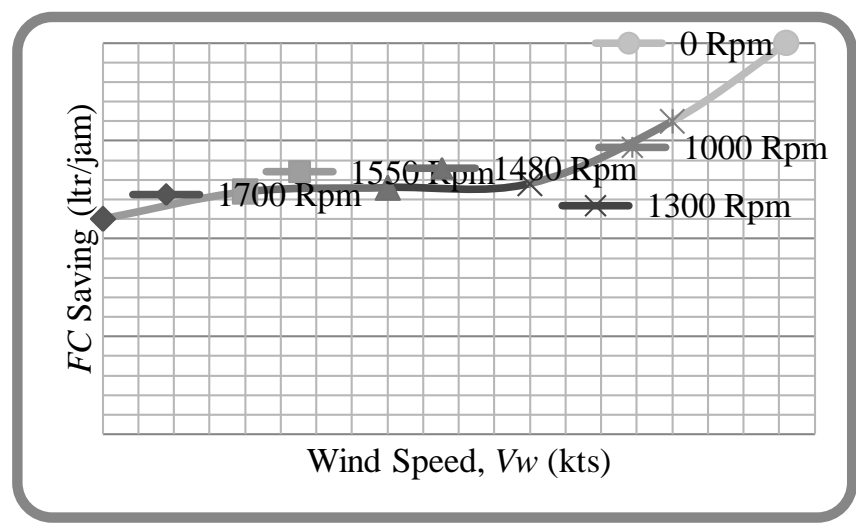

Figure 11. Result of CS2 use Vw-FC Saving Chart

Figure 10 shows the relationship between wind speed $(V w)$ and fuel consumption $(F C)$. Figure 11 also shows the efficiency/savings of fuel usage in ESV operations which alternately and fully utilize wind energy.

Service speed (Vs) on fishing boats is a major requirement because fishing vessels must arrive at the fishing ground as quickly as possible so as not to lose the right time to catch fish. This fishing vessel sailed with operational speed of around 9.8 knots. At this speed the ship will experience a drag force $(R T)$ of 6,423 $\mathrm{kN}$ with the need for thrust $(T)$ of $6.685 \mathrm{kN}$. To meet the needs of the thrust force is supplied from propeller propulsion $(T p)$ with a $2 \times 30 \mathrm{~kW}$ engine and sail $(T s)$ with an area $(A s) 125 \mathrm{~m}^{2}$. The optional of service speed is adjusted to the voyage profile of the fishing vessel itself. When the ship operates in the port area (departure from port) in an empty load state, the ship will only use a speed of about 2 to 3 knots. At this time the use of engines and sail is highly recommended. When the ship goes to the location of the fishing ground (outward bound) in an empty load state and after the ship is on the high seas it will use full service speed of 9.813 knots, because the fishing vessel must arrive at fishing ground according to the planned time (on time) by using the engine and sail simultaneously. When the ship arrives at the location of the fishing ground in an empty load state and then doing the fishing operation on the fishing ground will tend to use a speed of about 4 to 7 knots because the fishing equipment set up requires a rather fast time and if it is not quickly worried the fish will run all. At this time the use of machines and sail simultaneously / alternately is highly recommended depending on the situation. When the ship leaves the fishing ground location (homeward bound) to the port in full load condition with the catch, fulfillment of thrust force is generated from the use of the engine and sail simultaneously to reach speed service 9.813 knots. And when the ship arrives at the port (arrival at Port), the ship only uses its speed of about 2 to 3 knots by using the engine and sail alternately. The use of wind energy to drive ESV with service speed of $V s 9.813$ knots requires a $V w$ wind speed of 19.2 knots to produce a thrust force of $T$ of $6.685 \mathrm{kN}$.

\section{CONCLUSION}

Application of hybrid technology is very useful when applied to catamaran fishing vessels. The development of hybrid vessel gives a promising expectation in order to reduce the use of fossil fuels. It has been found that the use of sail in combination with the operation of engine (ESV) was to be very useful. Economic review indicates the potency of cost saving and could be save about $30 \%$ fuels consumption.

The system can reduce the emission of greenhouses gases. There is shown a good promise that can lead to significant savings in fuel consumption and hence reduce emission of greenhouse gases. The present work apparently portraits of study into the development of more energy efficient and less polluted fishing vessel.

\section{ACKNOWLEDGEMENT}

The author wished to thank the Ministry of Research, Technology and Higher Education (Kemenristekdikti) under BBPS Research Scheme to fund the current research. Furthermore, the first author, in particular, expressed his gratitude to YPTS- ITATS for the continuous support of the development of marine renewable energy on ship.

Conflict of Interest:

Authors declare no conflict of interest

\section{REFERENCES}

Pramudya IS, IKAP Utama, Wasis DA, 2017, Kapal Ikan Katamaran : Tinjauan Aspek Kebutuhan Energi, Fungsi dan Performa Kapal yang Ramah Lingkungan, Disertasi -MT093350.

Korol I. and Latorre, R., 2010, Development of Eco-Friendly Fishing Vessel An ecological vehicle powered by renewable energy, EVER Monaco. 
Utama IKAP., Setyawan, D, Jamaluddin, A, Sugiarso, A., 2010, Development of Catamaran Fishing Vessel, IPTEK, Journal for Technology and Science, Vol.21, No.4.

Molland AF., Turnock SR., Hudson DA., 2011, Ship Resistance and Propulsion - Practical Estimation of Ship Propulsive Power, ISBN:978-0-521-76052-2 Hardback, CUP, USA.

Marchaj, 2003, C A, Sail Performance, Techniques to Maximize Sail Power, Revised Edition, ACl, London.

Larson L., 2007, Principles of Yacht design, $3^{\text {rd }}$ ed.,ISBN-13: 9780071487696, Mc Graw Hill

Kinney, F.S., 1977, Skene's Element of Yacth Design, ISBN: 071361823x, ACB Ltd, London.

Richard Benny Luhulima, I Ketut Aria Pria Utama, Aries Sulisetyono, 2016, CFD Analysis inti the Resistance Interference of Displacement Trimaran, Australian Journal of Basic and Applied Sciences (AJBAS).

Richard Benny Luhulima, I Ketut Aria Pria Utama, Aries Sulisetyono, 2016, Experimental Investigation into the Resistance Components of Displacement Trimaran at Various Lateral Spacings, International Journal of Engineering Research \& Science (IJOER), 2016.

Utama, I K A P, , An Investigation into the Viscous Resistance Components of Catamarans, PhD Thesis, University of Southampton, UK, 1999.

Richard Benny Luhulima, Sutiyo, and I Ketut Aria Pria Utama, 2017, An Investigation Into The Correlation Between Resistance and Seakeeping Characteristics of Trimaran at Various Configuration and with Particular Case in Connection with Energy Efficiency.

P.I. Santosa, I.K.A.P Utama and W.D Aryawan, 2016, Power Estimation of HCFV Based on Voyage Profile, International Journal of Science and Research (IJSR), ISSN (Online): 2319-7064.

Hind, JA., 1982, Stability and Trim of Fishing Vessels - second edition, Fishing News Book Ltd, Farnham, Surrey, England.

P.I. Santosa, I.K.A.P Utama, W.D Aryawan, 2016, Power Estimation of HCFV Based on Voyage Profile, International Journal of Science and Research (IJSR) ISSN (Online): 2319-7064.

Pramudya Imawan Santosa, IKAP Utama, Wasis DA, 2017, A Study into the Development of More Energy Efficient and Less Polluted Fishing Vessel, International Journal of Engineering Research \& Science [IJOER], ISSN: 2395-6992, Vol-3, issue-10, October-2017.

P I Santosa, I K A P Utama, W D Aryawan, D B Purwanto, R-M Chao, and A Nasirudin, 2014, An Investigation into Hybrid Catamaran Fishing Vessel: Combination of Diesel Engine, Sails and Solar Panels, IPTEK, Journal of Proceeding Series, Vol. 1, 2014 (eISSN: 2354-6026). 